\title{
The Determinants of Informal Capital in the Financing of Small Firms at Start-Up: An Ethnic Comparison of Small Firms in Sweden
}

\author{
Darush Yazdanfar $^{1} \&$ Saeid Abbasian ${ }^{2}$ \\ ${ }^{1}$ Department of Social Science, Unit of Business Administration, Mid Sweden University, Sweden \\ ${ }^{2}$ Department of Social Science, Unit of Tourism Science \& ETOUR, Mid Sweden University, Sweden \\ Correspondence: Saeid Abbasian, Department of Social Science, Unit of Tourism Science \& ETOUR, Mid \\ Sweden University, Sweden. E-mail: saeid.abbasian@miun.se
}

Received: November 24, $2012 \quad$ Accepted: January 14, $2013 \quad$ Online Published: February 22, 2013

doi:10.5539/ijef.v5n3p62

URL: http://dx.doi.org/10.5539/ijef.v5n3p62

\begin{abstract}
This study explains empirically the differences in the use of informal financing between native- and immigrant-owned small businesses in terms of ethnicity and other relevant variables. A sample of 2814 nativeand immigrant-owned small businesses, consisting of a unique database gathered, was analysed and several univariate and multivariate methods employed. The results suggest that ethnicity is a significant explanatory variable and an important factor in informal capital access in the start-up stage in terms of loans from family members and friends. Moreover, the other independent variables, namely gender, age, experience of starting businesses, the amount of start capital, and firm size, affect loans from family members, whereas loans from friends are influenced by age, size, and industry affiliation. Since knowledge about informal capital determinants is limited, the results of this study add to our understanding of the variables that explain the financing behaviour of small businesses at start-up.
\end{abstract}

Keywords: small business finance, ethnicity, informal capital sources, start-up stage, bank loan

\section{Introduction}

Many problems, including financing, are common for both native-born and immigrant owners in the small business sector in western countries regardless of gender or ethnicity (Smallbone, Bertotti, \& Ekanem, 2005). Nevertheless, it is supposed that immigrants compared with native-born owners have considerable difficulties raising start-up capital (Ram, Theodorakopoulos, \& Jones, 2008; Ramangalahy, Brenner, Menzies, \& Filion, 2002).

According to Irwin and Scott (2010), ethnicity and gender are two significant variables that seem to be barriers to acquiring bank funding in the start-up phase. In this paper, we examine whether variables including ethnicity and gender influence access to financial sources, especially the role of informal capital in financing small firms in Sweden. By informal capital, we mean all financial support that is received in other ways than the formal route (i.e. banks and governmental authorities). This includes all loans, grants, and contributions by family members, friends, and relatives (Raijman \& Tienda, 2003; Piperopoulos, 2010; Rezaei, 2007).

\section{Previous Research}

Despite the general perception that owners of small firms have problems with funding (Berger \& Udell, 1995), it seems that both ethnicity and gender still matters, as several previous studies have used them as analytical tools. It is possible to correlate the significance of informal capital with numerous hypotheses and variables. Altinay and Altinay (2006), for example, suggested four general hypotheses and 22 variables such as ethnicity, age of owner, firm characteristics, and owner's education and language skills to find any possible correlation between the growth of small firms and these variables.

\section{Ethnicity}

Immigrants in general have less income than do native-born inhabitants (Cobb-Clarck \& Hildebrand, 2002). In addition, immigrant entrepreneurs show less likelihood than do their native counterparts to gain financial capital from mainstream credit institutions and banks (Ram \& Jones, 1998; Ram, Smallbone, \& Deaknis, 2002; Bruder, Neuberger, \& Räthke-Döppner, 2011). Further, different groups of immigrant entrepreneurs are treated by banks 
in different ways (Deakins, Ishaq, Smallbone, Whittam, \& Wyper, 2007), which means that the chance of taking out a bank loan is not equal for all immigrant groups/individuals. Moreover, the reliance on informal capital also varies by ethnic group (Basu \& Parker, 2001). In particular, immigrant-owned firms with no track records or mainstream networks in the host society face larger difficulties gaining funding from banks (Ofori, 2005; Cavalluzzo \& Wolken, 2005). Therefore, immigrant entrepreneurs mobilise their financial resources mostly through their own savings and ethnic informal sources rather than by formal mainstream networks (Bond \& Townsend, 1999; Huck, Rhine, Bond, \& Townsend, 1999).

\section{Gender}

Gender is a major factor in the likelihood to gaining informal capital. According to previous research, women face more problems than do men in raising venture capital or taking out bank loans (Greene, Brush, Hart, \& Saparito, 2001; Brush, Carter, Gatewood, Greene, \& Hart, 2004; Fuller-Love, Lim, \& Akehurst, 2006). Some research does not exclude the impact of existing general perceptions on different gender-based behavioural patterns (Robb \& Wolken, 2002; Huang \& Kisgen, 2008) that might affect banks' attitudes towards women and men.

Other authors (e.g. Fay \& Williams, 1993) discuss gender-based clichés combined with discrimination from financial institutions. Native-born female entrepreneurs are more often refused credit by banks and they pay more interest than their male counterparts do (Verheul, van Stel, \& Thurik, 2004; Muravyev, van Stel, \& Thurik, 2007). By contrast, they have a significantly greater likelihood than do immigrants of obtaining a bank loan (see, for example, Blanchflower, Levine, and Zimmerman, 2003). Women often start businesses with fewer resources compared with men (Carter \& Allen, 1997) and they often have fewer external sources of capital than men do (Brophy, 1989; Brush, 1992). This might be mostly due to discouragement (Kon \& Storey, 2003) or concern about being refused financing (Marlow \& Carter, 2006). The situation becomes even worse for female immigrants as they have less access to financial resources compared with both native-born women entrepreneurs and male counterparts from their own ethnic groups (Maltay, Scott, \& Whittam, 2011; Davidson, Fielden, \& Omar, 2010; Essers \& Benschop, 2007; Shanmuganthan, Spinder, Stone, \& Foss, 2003; Schrover, Van Der Leun, \& Quispel, 2007).

\section{Firm Characteristics}

Firm characteristics (e.g. size, legal form, industry affiliation/sector, age) are also considered to play a role in the differences in access to start-up capital among all business owners. Businesses owned by women and immigrants are generally smaller and younger than are male-owned businesses (Devine, 1994; Coleman, 1998; Hussain, Matlay, \& Scott, 2008). Blanchflower et al. (2003) and Cavalluzzo, Cavalluzzo, and Wolken (2002) showed that firm age, size, turnover, previous bankruptcy and creditworthiness, location, and industry affiliation might all play a role in favouring male and female native-born entrepreneurs over male and female minority entrepreneurs as well as favouring male native-born entrepreneurs against female native-born entrepreneurs.

Loscocco, Robinson, Hall, and Allen (1991) explained that female entrepreneurs have a disadvantage in accessing finance through a combination of the firm's and the owner's characteristics such as firm size (turnover) and income, lack of experience, and their concentration in the least profitable industries. Other studies have also shown that businesses owned by women and immigrants in contrast to those owned by male native-born entrepreneurs are highly concentrated to the services sector (Kalleberg \& Leicht, 1991; Hedberg, 2009). Firms operating in these traditional sectors rely more on personal savings and loans from family and friends, and less on bank loans (Ram, Smallbone, Deakins, \& Jones, 2003). Further, the legal form of the business has been used to analyse differences (Bressler \& Wiseman, 2011; Papadaki \& Chami, 2002).

\section{Owner Characteristics}

Owner characteristics have been examined to explain differences between small business owners' access to start-up capital. Human capital, especially educational level and language ability, have been examined as impact factors on immigrant business owners' chances of gaining bank loans compared with indigenous business owners (Rowley, 2004; Toussaint-Comeau, 2005; Altinay \& Altinay, 2008). Bates' (1997) study of Korean and Chinese entrepreneurs in the US confirmed that highly educated owners had much better access to bank loans than did less educated, who in turn mostly relied on their families and friends. Collins and Low (2010) reported that variables such as education and language ability play an important role in Asian women's self-entrepreneurship and in their success in Australia. Carter, Brush, Greene, Gatewood, and Harts (2003) suggested that there is a strong relation between the higher education of women and their odds of receiving external financing. 
The age of the owner has also been used as a possible factor that affects access to financial resources in several previous studies (e.g. Dhaliwal \& Kangis, 2006). Further, the owner's previous work experiences,, including previous experience of businesses plus outside work experience have also been used by several authors as analysis tools. Studies, for example, show that male and female entrepreneurs differ in previous experiences and professions, especially in prior entrepreneurial experiences (Brush, 1992; Verheul \& Thurik, 2001; Fischer, Reuber, \& Dyke, 1993). Papadaki and Chami (2002) counted 13 impact factors on the growth of small businesses, including outside work experience, previous businesses in the family, knowledge of the current industry, and previous ownership. Moreover, Yazdanfar and Jahandar (2011) showed that owners' previous experiences of starting up a business and outside work experience influence the use of external capital in the start-up stage.

Various authors emphasise the owner's own savings and how this affects financing or success in different terms. Although Kushnirovich and Heilbrunn (2008) emphasised access to own start-up capital, Basu (1998) found a strong relation between own savings (personal capital) plus the share of informal capital in the start-up, on one hand, and the success of the business, on the other hand. Cavalluzzo and Wolken (2005) suggested that personal wealth and credit history are possible explanations for the differences in receiving bank loans.

Other previous studies point to the cultural gap as an additional obstacle for ethnic groups when they apply for bank loans (Osili \& Paulson, 2005, 2006; Alesina \& La Ferrara, 2005). This induces immigrant-owned firms to prefer internal and informal capital sources to external and informal ones (Barrett, Jones, McEvoy, \& McGoldrick, 2002; Ram et al., 2003). Culture and cultural proximity can also be a reason why some immigrant groups are favoured or disfavoured by credit institutions (Albareto \& Mistrulli 2011; Estapé-Dubreuil \& Torreguitart-Mirada, 2010).

\section{Hypotheses}

Based on previous studies and our available data, the following hypotheses have been formulated. Unlike previous studies, the current research both uses a larger number of independent variables and has a larger sample.

Hypothesis 1: Ethnic background is significantly related to attitude towards informal capital in terms of loans from family members and friends in the start-up stage.

Hypothesis 2: Gender is significantly related to attitude towards informal capital in terms of loans from family members and friends in the start-up stage.

Hypothesis 3: Owner age is significantly related to attitude towards informal capital in terms of loans from family members and friends in the start-up stage.

Hypothesis 4: Previous experience is significantly related to attitude towards informal capital in terms of loans from family members and friends in the start-up stage.

Hypothesis 5: Outside work experience significantly influences attitude towards informal capital in terms of loans from family members and friends in the start-up stage.

Hypothesis 6: Educational level is significantly related to attitude towards informal capital in terms of loans from family members and friends in the start-up stage.

Hypothesis 7: Access to personal start-up capital is significantly related to attitude towards informal capital in terms of loans from family members and friends in the start-up stage.

Hypothesis 8: Firm size, in terms of number of employees, is significantly related to attitude towards informal capital in terms of loans from family members and friends in the start-up stage.

Hypothesis 9: The legal form of the firm is significantly related to attitude towards informal capital in terms of loans from family members and friends in the start-up stage.

Hypothesis 10: A firm's industrial sector is significantly related to attitude towards informal capital in terms of loans from family members and friends in the start-up stage.

\section{Data Sources and Model Specification}

\subsection{Data Sources}

The novel firm-level panel database used in this study was gathered by the Swedish Small Business Forum in the autumn of 2008. This data sample consists of all available small firms incorporated between 2005 and 2008 in four regions located in south-east Sweden. The preliminary sample covers 2832 firms. Firms with missing ethnic 
background variables were removed from the sample, leaving a final sample of 2510 native- and 304 immigrant-owned active small firms.

\subsection{Model Specification}

To investigate the hypotheses formulated earlier, a number of univariate analyses - including analysis of variance (ANOVA) - were employed as a first step to explore the differences between native- and immigrant-owned firms in access to informal start-up capital. Subsequently, a binary logistic regression model was implemented to identify the variables that can distinguish between Swedish native- and immigrant-owned firms with regard to patterns of informal capital acquisition in the start-up stage.

The value of the dependent variables in the model can vary between 0 and 1 . Those sample firms that have used a loan from family members or friends take a value of 1 , otherwise 0 (in other words, used $=1$ and not used $=0$ ). The underlying estimation equation in the binary logistic regression model can be shown as follows:

$$
y_{i}^{*}={ }_{0}+{ }_{1}(X 1)+{ }_{2}(X 2)+{ }_{3}(X 3)+{ }_{4}(X 4)+{ }_{5}(X 5)+{ }_{6}(X 6)+{ }_{7}(X 7)+{ }_{8}(X 8)+{ }_{9}(X 9)+\varepsilon
$$

where:

$y_{i}=$ Binary variable if the firm has used a certain type of funding source $y_{i}=1$; otherwise 0

${ }_{0}=$ Constant

The dependent variable in this study is informal capital in terms of loans from family members and friends.

$\mathrm{X} 1$ : Ethnicity (native: 1 , immigrant 2 )

X1: Gender (female: 1, male: 2)

$\mathrm{X} 3$ : Owner's age, natural logarithm of the age

X4: Earlier experience of starting up a business (Yes: 1, No: 0 )

X5: Outside work experience (Yes: 1, No: 0)

X6: University education (Yes: 1 , No: 0 )

X7: The owners' personal start-up capital, natural logarithm of amount

X8: Number of employees as a proxy of firm size, natural logarithm of the number of employees.

X9: Dummy variable for the legal form of firm has been coded as, less formalised legal form: sole proprietorships (1), trading partnerships as (2), and the most formalised legal form limited liability companies as (3).

X10: Dummy variable for industry has been coded: manufacturing sector with most physical capital (1), electronic or metal construction industries (2), transport (3), retail and wholesale (4), consulting and other services (5), and restaurants and related market segments (6). random error

\section{Empirical Results}

\subsection{Descriptive Analysis}

Descriptive statistics are used to report the key characteristics of the sample in general as well as separately for native- and immigrant-owned firms. The statistics contain the number of employees, amount of start-up capital, age of owner, earlier experience of starting up a business, outside work experience, university education, legal form, and industry affiliation.

As clearly shown by Table 1, there was no significant difference between the age of native- and immigrant-born owners of firms $(F=3.37, p=0.623)$. The average age of business owners was 42.5 years. On the question of whether owners had ever started or owned other businesses, around 35 per cent of respondents answered YES. In addition, more than 40 per cent of respondents expressed that they had outside work experience. However, there was no statistically significant difference between native and immigrant owners in terms of outside work experience $(F=2.66, p=10.36)$. Whereas 24.3 per cent of respondents had a secondary education, only 15.4 per cent had a university education. Native business owners had an almost similar educational level to that of immigrant owners, as the average university education levels did not differ significantly. Similarly, the average ages of native and immigrant owners did not differ significantly $(F=0.7852, p=37.62)$. 
Table 1. Mean, standard deviation, and number of variables included in the pooled sample

\begin{tabular}{llllllllll}
\hline & & Age & $\begin{array}{l}\text { Started businesses } \\
\text { before }\end{array}$ & $\begin{array}{l}\text { Outside } \\
\text { work experience }\end{array}$ & $\begin{array}{l}\text { University } \\
\text { education }\end{array}$ & $\begin{array}{l}\text { Number of } \\
\text { employees }\end{array}$ & $\begin{array}{l}\text { Start-up } \\
\text { capital }\end{array}$ & $\begin{array}{l}\text { Legal } \\
\text { form }\end{array}$ & $\begin{array}{l}\text { Industry } \\
\text { affiliation }\end{array}$ \\
\hline Natives & Mean & 42.650 & 1.655 & 1.576 & 1.819 & 1.966 & 3.840 & 20.390 & 3.249 \\
& Std. Deviation & 12.584 & 0.479 & 0.498 & 0.424 & 2.957 & 2.110 & 16.458 & 1.422 \\
& N & 2510 & 2510 & 2510 & 2510 & 2510 & 2510 & 2510 & 2510 \\
\multirow{2}{*}{ Immigrants } & Mean & 41.25 & 1.61 & 1.63 & 1.80 & 3.24 & 4.00 & 19.91 & 3.44 \\
& Std. Deviation & 11.95 & 0.51 & 0.50 & 0.43 & 14.01 & 2.00 & 15.79 & 1.62 \\
& N & 304 & 304 & 304 & 304 & 304 & 304 & 304 & 304 \\
& Mean & 42.50 & 1.65 & 1.58 & 1.82 & 2.10 & 3.86 & 20.34 & 3.27 \\
& Std. Deviation & 12.5228 & 0.4823 & 0.4985 & 0.4240 & 5.3938 & 2.0987 & 16.3851 & 1.4451 \\
& N & 2814 & 2814 & 2814 & 2814 & 2814 & 2814 & 2814 & 2814 \\
& F & 3.3786 & 2.5011 & 2.6606 & 0.7852 & 15.2834 & 1.4954 & 0.2344 & 4.9584 \\
& Sig. & 0.07 & 0.11 & 0.10 & 0.38 & 0.000 & 0.22 & 0.63 & 0.03 \\
& Welch test & 0.056 & 0.132 & 0.104 & 0.379 & 0.617 & 0.114 & 0.204 & 0.045
\end{tabular}

Levene statistic: test of homogeneity at the $0.05 \%$ level; Welch: robust tests of equality of means between the two groups at the $0.01 \%$ level. ANOVA at $0.05 \%$.

The statistical analysis of our sample indicated that firms are in general young micro firms established between 2005 and 2008. Interestingly, the size of native- and immigrant-owned firms in terms of number of employees is significantly different $(F$ test $=15.25, p=0.000)$; immigrant-owned firms have more employees than do native-owned firms ( $F$ test $=15.2, p=0.000$ ). Moreover, with regard to legal form, around 70 per cent of all sample firms are incorporated as sole proprietorships. The rest are incorporated as limited liability companies $(22 \%)$ and trading partnerships $(8 \%)$. The ANOVA results show that there is no significant difference between native- and immigrant-owned firms in terms of legal form $(F=0.23, p=62.83)$.

Concerning industrial affiliation, 57 per cent of all firms are active in the services sector, 18 per cent in the manufacturing sector, 12 per cent as retail firms, and the remaining 13 per cent are affiliated to other industries including transport, construction, restaurants, and consulting. The results confirm the significant difference in the mean scores of industry affiliation of native and immigrant-owned firms $(F=4.95, p=2.65)$.

\subsection{Sources of Start-Up Funds by Ethnic Background}

The descriptive statistics of differences between native- and immigrant-owned firms with regards to informal financing (i.e. loans from family members and friends) at start-up are shown in Table 2 . The results demonstrate the percentage of native- and immigrant-owned firms, respectively, which obtained capital from family members (25-37\%) and friends (4-20\%).

The majority of firms classified loans from family members as a first financing alternative $(26 \%)$ and loans from friends as a second option (6\%). Moreover, the sample is relatively characterised by a low standard deviation for both native and immigrant groups (Table 2).

Table 2. Sources of start-up funds by ethnic background

\begin{tabular}{llllll}
\hline Family members & Natives & $75 \%$ & $25 \%$ & 2,510 & 0.43 \\
& Immigrants & $63 \%$ & $37 \%$ & 304 & 0.48 \\
Friends & Total & $74 \%$ & $26 \%$ & 2,814 & 0.44 \\
& Natives & $96 \%$ & $4 \%$ & 2,510 & 0.19 \\
& Immigrants & $80 \%$ & $20 \%$ & 304 & 0.40 \\
& Total & $94 \%$ & $6 \%$ & 2,814 & 0.23 \\
\hline
\end{tabular}


Table 3 displays the mean, standard deviation and number of observation of dependent variables (Yes $=1$ and No $=0$ answers), showing the importance of loans from family members and friends as financing sources of firms in the start-up stage. The results show again that a higher proportion of immigrant-owned than native-owned firms use loans from family members or friends to start their firms.

Table 3. Mean, standard deviation and number of dependent variables

\begin{tabular}{llll}
\hline National & & Family members & Friends \\
\hline Natives & Mean & 1.250 & 1.039 \\
& Std. Deviation & 0.43 & 0.19 \\
& $\mathrm{~N}$ & 2,510 & 2,510 \\
Immigrants & Mean & 1.37 & 1.20 \\
& Std. Deviation & 0.48 & 0.40 \\
Total & $\mathrm{N}$ & 304 & 304 \\
& Mean & 1.26 & 1.06 \\
& Std. Deviation & 0.44 & 0.23 \\
& $\mathrm{~N}$ & 2,814 & 2,814 \\
\hline
\end{tabular}

\subsection{Test of Statistical Significance: ANOVA Test}

In this section, a significance test is performed to study which variables are statistically significant to explain the differences between the external financing of native and immigrant groups. The null hypothesis is there is no significant difference between native and immigrant groups concerning the use of different kinds of external capital in the start-up stage. As presented in Table 4, the results of the ANOVA show, on one hand, that statistically significant differences are found between native and immigrant groups regarding loans from family members and friends at the 5 per cent level. On the other hand, the differences concerning other sources, namely venture capital funding, government grants, funding from risk-capital companies, and other sources, are not statistically significant.

The validity tests of ANOVA, including Welch's test, Levene statistic, the and Jarque-Bera test (J-B test), confirm the robustness of the results. To investigate further, logistic regression analyses were carried out.

Table 4. ANOVA, Levene, and Welch tests of the dependent variables

\begin{tabular}{|c|c|c|c|c|c|c|c|c|c|}
\hline & & Sum of squares & df & Mean Square & $F$ & Sig. & $\begin{array}{l}\text { Welch } \\
\text { test }\end{array}$ & $\begin{array}{l}\text { Levene } \\
\text { statistic }\end{array}$ & $\begin{array}{l}\mathrm{J}-\mathrm{B} \\
p \text {-value }\end{array}$ \\
\hline \multirow{3}{*}{$\begin{array}{l}\text { Loans from } \\
\text { family } \\
\text { members }\end{array}$} & Between groups & 3.60673 & 1 & 3.60673 & 18.75236 & $0.000^{* *}$ & 0.000 & 0.000 & 0.000 \\
\hline & Within groups & 540.8453 & 2812 & 0.192335 & & & & & \\
\hline & Total & 544.452 & 2813 & & & & & & \\
\hline \multirow{4}{*}{$\begin{array}{ll}\text { Loans from } \\
\text { friends }\end{array}$} & Between groups & 6.762878 & 1 & 6.762878 & 132.7525 & $0.000^{* *}$ & 0.000 & 0.000 & 0.000 \\
\hline & Within groups & 143.2531 & 2812 & 0.050943 & & & & & \\
\hline & Total & 150.016 & 2813 & & & & & & \\
\hline & Total & 286.6951 & 2813 & & & & & & \\
\hline
\end{tabular}

Notes: **Coefficients are significant at the 0.05 level; Levene statistic - test of homogeneity at the $0.05 \%$ level; Welch t test - robust tests of equality of means between the groups and J-B $p$-value of means at the $0.05 \%$ level.

\subsection{Logistic Regression Analyses}

This section is based on the outcomes of four logistic regression analyses. It presents the empirical results, research findings, and diagnostic validation tests.

\subsubsection{Loans from Family Members}

In the first step, all the independent variables were entered into the binary logistic regression model. However, the independent variables in the final model are those that are most significant in explaining the changes in the dependent variable and non-significant variables have been removed from the model. As shown by the result of 
the first stepwise logistic regression, reported in Table 5, the significant variables that affect loans from family members are owners' ethnicity, gender, age, previous experience of starting a business, access to start-up capital, and firm size. These results support hypotheses 1, 2, 3, 4, 7, and 8. However, the results provide no support for the other hypotheses. Comparing the odds ratios (Exp (B)) of predictors, it can be confirmed that the change in the dependent variable (loans from family members) is largely explained by ethnicity (Exp B:1,699), previous experience of starting a company (Exp B:1,36), and firm size (Exp B:1,288). The size of the owner's personal start-up capital (Exp B:1,10), gender (Exp B:0,624), and age (Exp B:0,348) also play a role in explaining changes in loans from family members.

The validity of the model was examined by several diagnostic tests including the Omnibus test and Hosmer and Lemeshow. These tests yielded a Chi-square value $(\chi 2=60,4 p=0.000<0,05)$ that showed that the explanatory variables included in the model significantly affect the independent variable (loans from family members). Moreover, the model has a Hosmer-Lemeshow goodness of fit $(\chi 2=9.8, p=0,27>0.05)$ and overall correctly classified 73.7 per cent of the cases included in the sample. The results of the Cox and Snell tests and Nagelkerke R squared also indicate that more than 21 and 31 per cent of the variation in the dependent variable is explained by the set of independent variables. The Wald statistics provide further evidence of the significance of the coefficients in the estimated model.

Table 5. First and second stepwise logistic regression analyses: dependent variables: loans from family members, loans from friends

\begin{tabular}{|c|c|c|c|c|c|c|}
\hline Loans from family members & $\mathrm{B}$ & S.E. & Wald & Df & Sig. & $\operatorname{Exp}(B)$ \\
\hline Ethnicity & 0,53034 & 0,12998 & 16,6471 & 1 & 0,00005 & 1,69951 \\
\hline Gender & $-0,47026$ & 0,08323 & 31,9194 & 1 & 0,00000 & 0,62484 \\
\hline Age & $-1,05425$ & 0,34309 & 9,44184 & 1 & 0,00212 & 0,34845 \\
\hline Experience of starting businesses before & 0,31282 & 0,09874 & 10,0359 & 1 & 0,00154 & 1,36728 \\
\hline Start-up capital & 0,10037 & 0,02235 & 20,1700 & 1 & 0,00001 & 1,10559 \\
\hline Size & 0,25371 & 0,11952 & 4,50558 & 1 & 0,03378 & 1,28880 \\
\hline \multirow[t]{2}{*}{ Constant } & $-0,13195$ & 0,66958 & 0,03883 & 1 & 0,84378 & 0,87638 \\
\hline & Chi-square & Df & Sig. & Classification accuracy & 73.83 & \\
\hline Omnibus tests & 95,2288 & 6 & 0.0000 & Cox and Snell tests & 0,0332749 & \\
\hline Hosmer and Lemeshow test & 19,3383 & 8 & 0,01315 & Nagelkerke R squared & 0,0486744 & \\
\hline Wald & 582,390 & 1 & 0.0000 & -2 Log likelihood & 3143,166 & \\
\hline Loans from friends & $\mathrm{B}$ & S.E. & Wald & Df & Sig. & $\operatorname{Exp}(B)$ \\
\hline Ethnicity & 1,72553 & 0,17946 & 92,4465 & 1 & 0,0000 & 5,61554 \\
\hline Age & $-2,20025$ & 0,64121 & 11,7744 & 1 & 0,0006 & 0,11077 \\
\hline Size & 0,44002 & 0,16775 & 6,88005 & 1 & 0,0087 & 1,55274 \\
\hline Industry & 0,16188 & 0,05799 & 7,79230 & 1 & 0,0052 & 1,17572 \\
\hline \multirow[t]{2}{*}{ Constant } & $-2,05317$ & 1,06604 & 3,70939 & 1 & 0,0541 & 0,12832 \\
\hline & Chi-square & Df & Sig. & Classification accuracy & 94,3496802 & \\
\hline Omnibus tests & 113,5314 & 4 & 0.0000 & Cox and Snell tests & 0,03954216 & \\
\hline Hosmer and Lemeshow test & 10,87728 & 8 & 0,20875 & Nagelkerke R squared & 0,11221046 & \\
\hline Wald & 1189,01 & 1 & 0.0000 & -2 Log likelihood & $1109,070 \mathrm{a}$ & \\
\hline
\end{tabular}

Notes: All regression coefficients are significant at the 0.05 level of significance $(p=0.000)$.

\subsubsection{Loans from Friends}

Table 5 reports the results of the second binary logistic regression model testing the hypotheses formulated in section 1.1. As the findings show, in agreement with hypotheses $\mathbf{1 , 2 , 8}$, and 10 , four independent variables ethnicity, owners' age, firm size, and industry affiliation - are found to be significant at the 5 per cent level. However, the results provide no evidence supporting the other hypotheses regarding the impact of other explanatory variables on loans from friends. Thus, ethnicity, firm size, and industry affiliation influence the variable loans from friends positively, while owners' age is negatively related in this respect. 
As shown by the diagnostic tests, the Omnibus $\left(\chi^{2}=113.5, p=0.0000<0.05\right)$, Hosmer and Lemeshow $(\chi 2=$ $10.877, p=0.20875>0.05)$, and Wald $(\chi 2=1189, p=0.000<0.05)$ tests all confirm the statistical significance of the results. Moreover, the estimated model explains between 39.5 and 22.1 per cent of the variance (Cox and Snell $R 2$ and Nagelkerke, respectively), confirming an association between the dependent and independent variables. The classification accuracy ratio of the model, which compares the prognosticated in relation to the observed results, implies very good classification power of the variables (94.3).

To sum up, the explanatory variable ethnicity has a positive impact on the acquisition of informal capital in terms of loans from family members and friends. In similarity with Irwin and Scott's (2010) results we found that ethnicity is significant barrier to receiving bank funding in the start-up phase, whilst in contrast to their results we found that also gender constitutes barrier. Such barriers in turn motivate immigrant and female entrepreneurs to borrow from the most accessible source, namely family members. In addition, the impact of gender on loans from family members is negative, indicating that male owners tend to rely less on this financing source than do their female counterparts. However, gender has no influence on loans from friends. The findings also show that age has a negative effect on loans from family members and friends. This is different from previous research (see Dhaliwal and Kangis, 2006). Whereas the experience of starting up businesses before and the amount of start-up capital positively influence loans from family members, they have no effect on loans from friends. Industry affiliation, which is positively related to loans from family members, has no influence on loans from friends. Finally, the size of firms is positively related to both types of informal capital. Surprisingly, and in contrast to the common perception in research, immigrant-owned firms in this sample are larger than are those owned by native- born firms.

\section{Conclusion}

The increasing importance of entrepreneurship in job creation among immigrants has been acknowledged in the literature. Given that the availability of capital plays a vital role in starting a business, this study focuses on the role of ethnicity and other relevant variables in using informal financing in the start-up stage. One of the main findings of the study is that owners' ethnicity is significant in explaining differences between native- and immigrant-owned firms in terms of the use of informal capital. Thus, immigrant-owned firms tend to rely more on loans from family members and friends than do native-owned firms.

Furthermore, the findings provide evidence that immigrant-owned firms use more loans from family members and friends than do native-owned firms. Gender has no association with loans from friends. Since age has a negative effect on loans from family members and friends, older firm owners tend to use informal capital more often compared with younger counterparts. In addition, whereas the impact of experience of starting businesses earlier and the amount of start-up capital on loans from family members is significant and positive, these also influence loans from friends. Moreover, industry affiliation, which is positively related to loans from family members, is related to loans from friends. Finally, firm size is positively related to both types of informal capital.

\section{References}

Albareto, G., \& Mistrulli, P. E. (2011). Bridging the gap between migrants and the banking system. Working paper 794, Banca D'Italia Eurosistema.

Alesina, A., \& La Ferrara, E. (2005). Ethnic Diversity and Economic Performance. Journal of Economic Literature, 43(3), 762-800. http://dx.doi.org/10.1257/002205105774431243

Altinay, L., \& Altinay, E. (2006). Determinants of Ethnic Minority Entrepreneurial Growth in the Catering Sector. The Service Industries Journal, 26(2), 203-221. http://dx.doi.org/10.1080/02642060500369354

Altinay, L., \& Altinay, E. (2008). Factors influencing business growth: the rise of Turkish entrepreneurship in the UK. International Journal of Entrepreneurial Behaviour \& Research, 14(1), 24-46. http://dx.doi.org/10.1108/13552550810852811

Andersson, P. (2006). Four Essays on Self-Employment. Swedish Institute for Social Research, Stockholm University: Stockholm.

Barrett, G., Jones, T., McEvoy, D., \& McGoldrick, C. (2002). The economic embeddedness of immigrant enterprise in Britain. International Journal of Entrepreneurial Behaviour \& Research, 8(1/2), 11-31. http://dx.doi.org/10.1108/13552550210423697

Basu, A. (1998). An exploration of entrepreneurial activity among Asian small businesses in Britain. Small Business Economics, 10(4), 313-326. http://dx.doi.org/10.1023/A:1007956009913 
Basu, A., \& Parker, S. C. (2001). Family finance and new business start-ups. Oxford Bulletin of economics and Statistics, 63(3), 333-358. http://dx.doi.org/10.1111/1468-0084.00224

Bates, T. (1997). Financing small business creation: The case of Chinese and Korean immigrant entrepreneurs. Journal of Business Venturing, 12(2), 109-124. http://dx.doi.org/10.1016/S0883-9026(96)00054-7

Berger, A. N., \& Udell, F. G. (1995). Relationship lending and lines of credit in small firm finance. Journal of Business, 68(3), 351-381. http://dx.doi.org/10.1086/296668

Blanchflower, D. G., Levine, P. B., \& Zimmerman, D. J. (2003). Discrimination in the small-business credit

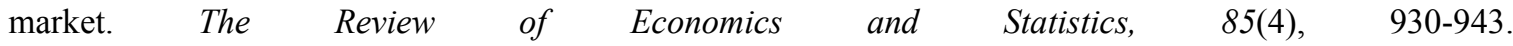
http://dx.doi.org/10.1162/003465303772815835

Bond, P., \& Townsend, R. (1999). Formal and informal financing in a Chicago ethnic neighbourhood. Economic Perspectives (II), Federal Reserve Bank of Chicago, pp. 3-27.

Bressler, M. S., \& Wiseman, M. (2011). Understanding Asian-American businesses and their role in economic growth and development. Research in Business and Economics Journal, 4, 10. Retrieved from http://www.aabri.com/rbej.html.

Brophy, D. (1989). Financing women owned entrepreneurial firms. In Hagan, O., Rivchun, C., \& Sexton, D. (Eds.), Women Owned Businesses (pp. 55-76). New York: Praegar.

Bruder, J., Neuberger, D., \& Räthke-Döppner, S. (2011). Financial constraints of ethnic entrepreneurship: evidence from Germany. International Journal of Entrepreneurial Behaviour \& Research, 17(3), 296-313. http://dx.doi.org/10.1108/13552551111130727

Brush, C. (1992). Research on women business owners: past trends, a new perspective and future directions. Entrepreneurship Theory and Practice, 16(1), 5-30.

Brush, C., Carter, N. M., Gatewood, E., Greene, P. G., \& Hart, M. M. (2004). Clearing the Hurdles: Women Building High-Growth Businesses. FT/Prentice Hall. Upper Saddle River, NJ.

Carter, N. M., \& Allen, K. R. (1997). Size determinants of women-owned businesses: choice or barriers to resources? Entrepreneurship and Regional Development, 9(3), 211-220. http://dx.doi.org/10.1080/08985629700000012

Carter, N. M., Brush, C. G., Greene, P. G., Gatewood, E., \& Harts, M. M. (2003). Women entrepreneurs who break through to equity financing: the influence of human, social and financial capital. Venture Capital, 5(1), 1-28. http://dx.doi.org/10.1080/1369106032000082586

Cavalluzzo, K. S., \& Wolken, J. D. (2005). Small business loan turndowns, personal wealth and discrimination. Journal of Business, 78(6), 2153-2178. http://dx.doi.org/10.1086/497045

Cavalluzzo, K. S., Cavalluzzo, L. C., \& Wolken, J. D. (2002). Small business financing, and discrimination: Evidence from a new survey. The Journal of Business, 75(4), 641-679. http://dx.doi.org/10.1086/341638

Cobb-Clarck, D., \& Hildebrand, V. (2002). The wealth and Asset Holdings of US and Foreign Born Households: Evidence from SIPP data. Discussion Paper 674 from the Institute for the study of Labor: Bonn, Germany. December 2002. Retrieved may 2012 from: www.iza.org.

Coleman, S. (1998). Access to capital: a comparison of men and women-owned small businesses. Paper presented at The Babson-Kauffman Entrepreneurship Research Conference, 21 May, Gent: Belgium.

Collins, J., \& Low, A. (2010). Asian female immigrant entrepreneurs in small and medium-sized businesses in Australia. Entrepreneurship \& Regional Development, 22(1), 97-111. http://dx.doi.org/10.1080/08985620903220553

Davidson, M. J., Fielden, S. L., \& Omar, A. (2010). Black, Asian and Minority Ethnic female business owners: Discrimination and social support. International Journal of Entrepreneurial Behaviour \& Research, 16(1), 58-80. http://dx.doi.org/10.1108/13552551011020072

Deakins, D., Ishaq, M., Smallbone, D., Whittam, G., \& Wyper, J. (2007). Ethnic minority business in Scotland and the role of social capital. International Small Business Journal, 25(3), 307-326. http://dx.doi.org/10.1177/0266242607076530

Devine, T. J. (1994). Characteristics of self-employed women in the United States. Monthly Labour Review, 117(3), 20-34. 
Dhaliwal, S., \& Kangis, P. (2006). Asians in the UK: gender, generations and enterprises. Equal Opportunities International, 25(2), 92-108. http://dx.doi.org/10.1108/02610150610679529

Essers, C., \& Benschop, Y. (2007). Enterprising identities: Female entrepreneurs of Moroccan and Turkish origin in the Netherlands. Organization Studies, 28(1), 49-69. http://dx.doi.org/10.1177/0170840607068256

Estapé-Dubreuil, G., \& Torreguitart-Mirada, C. (2010). Microfinance and gender consideration in developed countries: the case of Catalonia. Management Research Review, 33(12), 1140-1157. http://dx.doi.org/10.1108/01409171011092194

Fay, M., \& Williams, L. (1993). Gender bias and the availability of business loans. Journal of Business Venturing, 8(4), 363-377. http://dx.doi.org/10.1016/0883-9026(93)90005-P

Fischer, E., Reuber, R., \& Dyke, L. (1993). A theoretical overview and extension of research on sex, gender, and entrepreneurship. Journal of Business Venturing, 8(2), 151-168. http://dx.doi.org/10.1016/0883-9026(93)90017-Y

Fuller-Love, N., Lim, L., \& Akehurst, G. (2006). Guest editorial: Female and ethnic minority entrepreneurship. International Entrepreneurship and Management Journal, 2(4), 429-439. http://dx.doi.org/10.1007/s11365-006-0007-y

Greene, P. G., Brush, C. G., Hart, M. M., \& Saparito, P. (2001). Patterns of venture capital funding: is gender a factor? Venture Capital: An International Journal of Entrepreneurial Finance, 3(1), 63-83.

Hedberg, C. (2009). Intersections of Immigrant Status and Gender in the Swedish Entrepreneurial Landscape. Working Paper 8, Stockholm University Linnaeus Center for Integration Studies (SULCIS).

Huang, J., \& Kisgen, D. J. (2008). Gender and corporate finance. Paper presented at USC FBE Finance Seminar, October. Los Angeles, CA.

Huck, P., Rhine, S., Bond, P., \& Townsend, R. (1999). Small business finance in two Chicago Minority neighborhoods. Economic Perspectives, 23(2), 46-62.

Hussain, J., Matlay, H., \& Scott, J. (2008). Financial education in small ethnic minority businesses in the UK. Education and Training, 50(8/9), 737-747. http://dx.doi.org/10.1108/00400910810917109

Irwin, D., \& Scott, J. M. (2010). Barriers faced by SMEs in raising bank finance. International Journal of Entrepreneurial Behavior \& Research, 16(3), 245-259. http://dx.doi.org/10.1108/13552551011042816

Kalleberg, A. L., \& Leicht, K. T. (1991). Gender and organizational performance: Determinants of small business survival and success. Academy of Management Journal, 34(1), 136-161. http://dx.doi.org/10.2307/256305

Kon, Y., \& Storey, D. J. (2003). A theory of discouraged borrowers. Small Business Economics, 21(1), 37-49. http://dx.doi.org/10.1023/A:1024447603600

Kushnirovich, N., \& Heilbrunn, S. (2008). Financial funding of immigrant businesses. Journal of Developmental Entrepreneurship, 13(2), 167-184. http://dx.doi.org/10.1142/S1084946708000910

Loscocco, K. A., Robinson, J., Hall, R. H., \& Allen, J. K. (1991). Gender and small business success: An Inquiry into women's relative disadvantage. Social Forces, 70(1), 65-85.

Maltay, H., Scott, M., \& Whittam, G. (2011). Ethnic entrepreneurship in reverse in the UK: Is there gender bias in access to finance for South Asian women entrepreneurs? Paper presented at the $56^{\text {th }}$ Annual ISCB World Conference, Stockholm: Sweden.

Marlow, S., \& Carter, S. (2006). If you don't ask you don't get! Women, self-employment and finance. Paper presented to Warwick Business School Small Firms Finance Conference, May, Coventry, UK.

Muravyev, A., Schäfer, D., \& Talavera, O. (2007). Entrepreneurs' gender and financial constraints: Evidence from international data. Working paper from German Institute for Economic Research (DIW) and European University Institute. July 16, 2007: Berlin: Germany.

Ofori, S. K. A. (2005). Financing the UK "Immigrant -entrepreneurs" sector: Policy, Practices and Opportunity. Working paper from The Durham Law School and Durham Business School: Durham University.

Osili, U. O., \& Paulson, A. (2005). Institutions and Financial Development: Evidence from International Migrants in the U.S. Federal Reserve Bank of Chicago. Working Paper No. 2004-19. 
Osili, U. O., \& Paulson, A. (2006). What Can We Learn about Financial Access from U.S. Immigrants? Federal Reserve Bank of Chicago, Working Paper No. 2006-25.

Papadaki, E., \& Chami, B. (2002). Growth Determinants of Micro-businesses in Canada. Small Business Policy Branch Industry, Canada.

Piperopoulos, P. (2010). Ethnic minority businesses and immigrant entrepreneurship in Greece. Journal of Small Business and Enterprise Development, 17(1), 139-158. http://dx.doi.org/10.1108/14626001011019170

Raijman, R., \& Tienda, M. (2003). Ethnic foundations of economic transactions: Mexican and Korean immigrant entrepreneurs in Chicago. Ethnic and Racial Studies, 26(5), 783-801. http://dx.doi.org/10.1080/0141987032000109032

Ram, M., \& Jones, T. (1998). Ethnic Minorities in business. Small Business Research Trust, Report January. Open University Business School: UK. http://dx.doi.org/10.1080/1369183032000123440

Ram, M., Smallbone, D., \& Deaknis, D. (2002). Ethnic Minority Business in UK: Access to Finance and Business Support. London: British Bankers Association. http://dx.doi.org/10.1177/0950017008093479

Ram, M., Smallbone, D., Deakins, D., \& Jones, T. (2003). Banking on break out: Finance and the development of Ethnic Minority Businesses. Journal of Ethnic and Migration Studies, 29(4), 663-681.

Ram, M., Theodorakopoulos, N., \& Jones, T. (2008). Forms of capital, mixed embeddedness and Somali enterprise. Work, employment and society, 22(3), 427-446.

Ramangalahy, C., Brenner, G. A., Menzies, T. V., \& Filion, L. J. (2002). Ethnic enterprise Start up stage: An Empirical survey among the Chinese, Italian and Sikh entrepreneurial communities. Working paper no 15, at McGill Conference on International entrepreneurship: Researching New frontiers, September $13^{\text {th }}$ to $16^{\text {th }}$, 2002, McGill University, Montreal, Canada.

Rezaei, S. (2007). Breaking out: The dynamics of immigrant owned businesses. Journal of Social Science, 3(2), 94-15.

Robb, A., \& Wolken, J. D. (2002). Firm, owner, and financing characteristics: differences between female- and male-owned small businesses. Federal Reserve System Research Paper Series - FEDS Papers, Working paper No. 18, March. Page nos: 28. Washington: USA.

Rowley, T. (2004). Entrepreneurship Means Adaptation. Retrieved from http://www.matr.net/print-12097.html (accessed 22 October 2012).

Schrover, M., Van Der Leun, J., \& Quispel, C. (2007). Niches, labour market segregation, ethnicity and gender. Journal of Ethnic and Migration Studies, 33(4), 529-540. http://dx.doi.org/10.1080/13691830701265404

Shanmuganthan, P., Spinder, D., Stone, M., \& Foss, B. (2003). Does ethnic focus change how banks should implement customer relationship management? Journal of Financial Services Marketing, 8(1), 49-62. http://dx.doi.org/10.1057/palgrave.fsm.4770106

Smallbone, D., Bertotti, M., \& Ekanem, I. (2005). Diversification in ethnic minority business- the case of Asians in London's creative industries. Journal of Small Business and Enterprise Development, 12(1), 41-56. http://dx.doi.org/10.1108/14626000510579635

Toussaint-Comeau, M. (2005). Self-employed immigrants: An analysis of recent data. Chicago Fed Letter, No 213. April, 4 pages.

Verheul, I., \& Thurik, R. (2001). Start-up capital: Does gender matter? Small Business Economics, 16(4), 329-346. http://dx.doi.org/10.1023/A:1011178629240

Verheul, I., van Stel, A., \& Thurik, R. (2004). Explaining female and male entrepreneurship across 29 countries. Discussion Paper nr 0804 on Entrepreneurship, Growth and Public Policy. Max Planck Institutet for Research into Economic Systems Group Entrepreneurship, Growth and Public Policy, Jena: Germany. Page nos: 32 .

Yazdanfar, D., \& Jahandar, S. (2011). Acquisition of external capital at start-up stage: Differences between Swedish female- and male-owned firms. International journal of Entrepreneurship and Small Business, 15(4), 435-451. http://dx.doi.org/10.1504/IJESB.2012.046474 